\title{
MERE MOLINISM: A DEFENSE OF TWO ESSENTIAL PILLARS
}

\author{
Tim STRATTON and JACOBUS ERASMUs*
}

North-West University

\begin{abstract}
Molinism is founded on two 'pillars', namely, the view that human beings possess libertarian free will and the view that God has middle knowledge. Both these pillars stand in contrast to naturalistic determinism and divine determinism. In this article, however, the authors offer philosophical and theological grounds in favor of libertarian free will and middle knowledge.
\end{abstract}

KEY WORDS: Molinism, determinism, Calvinism, libertarian free will, middle knowledge

\section{Introduction}

Over the past two millennia, Christians have both agreed and disagreed on many theological issues. [The arguments in this chapter were inspired by Tim Stratton's doctoral research that is still in progress. He plans to use the arguments in this chapter (among others) in his PhD dissertation.] These disagreements continue in abundance today, often with ferocity. Despite these passionate differences, what has kept Christians united over all this time is what C. S. Lewis referred to as 'mere Christianity'. Keeping it 'mere' means focusing on the simple statement that 'God raised Jesus from the dead'. If this one proposition is true, then Mere Christianity is true as well. The Apostle Paul made this clear when he declared, 'And if Christ has not been raised, then our preaching is in vain and your faith is in vain' (1 Corinthians 15:14). [All translations of Scripture come from the ESV.]

If the Christian faith hinges on God's raising Jesus from the dead, then this is one subject Christians should not argue about. However, this leaves numerous other topics open for discussion and debate. These debates have ranged from how to interpret the creation account in Genesis to how to interpret the eschatological visions in Revelation and many other issues in between. One of the main issues dividing many Christians today is how to reconcile God's providence and sovereignty with human freedom and re-

* TIM STRATTON (MA 2014, Biola University) is a PhD candidate in Systematic Theology at North-West University. Email: tim@freethinkingministries.com.

JACOBUS ERASMUS (PhD 2015, North-West University) is Postdoctoral Fellow in Philosophy at North-West University. Email: je@jacobuserasmus.com. 
sponsibility. Over the past five hundred years, most Protestant Christians have settled into one of two camps: Calvinism (based on the teachings of John Calvin) and Arminianism (based on the teachings of Jacob Arminius). Many have assumed that these are the only alternatives. However, there are other options to consider (e.g., Molinism and open theism) and, thus, this dichotomy is a false dilemma.

The authors have argued that any view espousing divine determinism creates major difficulties for the Christian. To be specific, Calvinism (as commonly taught and understood) leads inevitably to the conclusion that God is neither omnibenevolent nor all-loving. On the other hand, a strict Arminianism is also problematic, as it diminishes either God's eternal omniscience or his omnipotence (which lies beyond the scope of this article). Since Scripture teaches that God is omnibenevolent, omnipotent, and omniscient, the view presented here would not diminish any of God's essential divine attributes. The authors hold that the most attractive solution is Molinism since it leaves all God's omni-attributes unscathed, and it offers a sound explanation as to how God can predestine all things without causally determining all things. [A full account of Molina's doctrine of predestination is furnished by MacGregor (2015: 133-157).]

Molinism is based on the writings of Luis de Molina (1535-1600), a Spanish Jesuit theologian, philosopher, and priest. As with the Protestant Reformers of his day, Molina believed the Catholic Church was in dire need of reformation; however, he believed he could bring more change to the church by working for reform from within Catholicism (MacGregor 2015: 12-14). Because of the doctrinal tsunami created in the early seventeenth century by Arminius and the Remonstrants vis-à-vis the Synod of Dort, Molina's work was engulfed and all but lost to Protestant theology for nearly half a millennium. For Arminians incorrectly believed that Arminius had captured all valid insights from Molina and so ignored the Catholic Reformer, and Calvinists incorrectly identified Molina's views with those of Arminius and so renounced Molina's works in a case of guilt by association. Molina's work, however, finally caught a breath four decades ago when it was revivified by Alvin Plantinga. Today Molina's views are becoming increasingly popular among theologians, philosophers, and biblical scholars. Those who find Molina's views concerning God's sovereignty convincing have become known as 'Molinists'.

While Molinists do not agree on all issues, 'Mere Molinism' nevertheless simply affirms two essential propositions, which might be called the 'Two Pillars of Molinism'. They are the following:

1. Humans have libertarian free will.

2. God has middle knowledge. 
In this article, we will defend these two pillars of Molinism. Let us begin, then, by discussing libertarian free will.

\section{Libertarian Free Will}

Libertarianism is the view that free will is incompatible with determinism (the view that past events necessarily entail subsequent events) and that some of our actions are free (note that libertarianism does not require all of one's actions to be free). But what, exactly, is a 'free action'? First, by action we mean either a physical action, such as raising one's hand to vote, or a mental action, such as willing to raise one's hand to vote. Hence, if one's hand is tied down and cannot be raised, and if one wills or tries to raise one's hand, then one is performing an action (even if the physical act cannot actually be performed). Second, by calling an agent's action free we mean the agent is ultimately responsible for the action, and an agent is ultimately responsible for an action if and only if the action is either a characterforming action or sufficiently explained by the agent's character and motives. A character-forming action is an intentional and rational action (i) that the agent can either perform or refrain from performing and (ii) that occurs when an agent decides between competing choices, and only at the moment of decision does the agent determine which choice he or she desires more; such a decision forms the agent's character. Accordingly, an agent has libertarian free will if and only if the agent performs, has performed, or can perform a free action. Hereafter, we will use the terms 'libertarian free will' and 'free will' synonymously and in the sense described above.

As with many philosophical issues, free will is a controversial topic. The idea that we have free will is attacked by many people on both sides of the theistic aisle, including naturalists and theists. In fact, most naturalists (such as Richard Dawkins, Stephen Hawking, Sam Harris, Will Provine, Alex Rosenberg, and Jerry Coyne) argue that free will is an illusion. Hawking writes, 'It is hard to imagine how free will can operate if our behavior is determined by physical law, so it seems that we are no more than biological machines and that free will is just an illusion.' He concludes that 'human behavior is indeed determined by the laws of nature' and our actions are 'as determined as the orbits of the planets' (Hawking 2010: 32). The 'New Atheist' philosopher, neuroscientist, and best-selling author Sam Harris agrees. In his recent book, Free Will, Harris writes:

Free will is an illusion. Our wills are simply not of our own making. Thoughts and intentions emerge from background causes of which we are unaware and over which we exert no conscious control. We do not have the freedom we think we have. Free will is actually more than an illusion (or less), in that it cannot be made conceptually coherent. Either our wills are determined by prior causes and 
we are not responsible for them, or they are the product of chance and we are not responsible for them (Harris 2012: 5).

On the other side of the aisle are some theists, such as theological or divine determinists (many Calvinists). According to them, God causally determines all things, such that all things fall outside human control. Humans, therefore, have no genuine responsibility over anything (including their own behaviors and beliefs). For example, John Calvin argues in his Institutes of the Christian Religion that God

determined with himself whatever he wished to happen with regard to every man... We hold that God is the disposer and ruler of all things, that from the remotest eternity, according to his own wisdom, he decreed what he was to do, and now by his power executes what he decreed. Hence we maintain, that by his providence, not heaven and earth and inanimate creatures only, but also the counsels and wills of men are so governed as to move exactly in the course which he has destined (Calvin 1845: 2206, 179).

Calvin also believed that all events are predestined, and the authors agree. However, most Calvinists assume (as Calvin seemed to think) that if all things are predestined, then all things must be causally determined by God. If God predestines all things by causally determining all things, then the 'counsels and wills of men are so governed' and are not 'up to them'. Rather, the wills of humans are determined by God. There is no room for libertarian free will in Calvin's view. To use Calvin's own words:

How few are there who, when they hear free will attributed to man, do not immediately imagine that he is the master of his mind and will in such a sense, that he can of himself incline himself either to good or evil?... Of this, the very term in question [free will] furnishes too strong a proof... I think the abolition of it would be of great advantage to the Church. I am unwilling to use it myself; and others, if they will take my advice, will do well to abstain from it (Calvin 1845: 229-230).

Both the naturalistic atheist like Sam Harris and the theistic determinist like John Calvin seem to agree that things external to humanity govern and control humanity. According to both, this includes the wills and intentions of humanity. Naturalists and divine determinists are odd bedfellows, to be sure; nevertheless, they offer a united front proclaiming that free will is an illusion.

So, do humans have free will? Are some of our thoughts, actions, beliefs, and behaviors ultimately up to us? Or are all of these things determined by external factors? Some might contend it is a properly basic belief that humanity possesses libertarian freedom. After all, it definitely seems as if we 
make choices every day that are ultimately up to us. Moreover, many contend that the ability to make moral choices requires libertarian free will. While good arguments can be made supporting these propositions, the authors believe there is one reason to affirm free will that supersedes the rest. That reason is the ability to reason. That is to say, beliefs can be rationally affirmed only if humans possess libertarian free will. Consider the Freethinking Argument:

1. If naturalism is true, the immaterial human soul does not exist.

2. If the soul does not exist, libertarian free will does not exist.

3. If libertarian free will does not exist, rationality and knowledge do not exist.

4. Rationality and knowledge exist.

5. Therefore, libertarian free will exists.

6. Therefore, the soul exists.

7. Therefore, naturalism is false.

8. The best explanation for the existence of the soul is God.

The first three steps of the argument are rather straightforward. In a nutshell, (1) is synonymous with 'if naturalism is true, nature is all that exists'. (2) is tantamount to 'if all that exists is nature, then all that exists is causally determined via the laws of nature, the initial conditions of the Big Bang, and things external to human control'. (3) is equivalent with 'if all things are causally determined, then that includes all thoughts and beliefs'. If our thoughts and beliefs are forced upon us and we could not have chosen better beliefs, then we are simply left assuming that our determined beliefs are good (let alone true). Therefore, we could never rationally affirm that our beliefs really are the inference to the best explanation; we can only assume it.

This, then, is the big problem for the atheistic naturalist or the Calvinist who affirms determinism: if exhaustive determinism is true, then atheists, Calvinists, or anyone else for that matter, cannot possess knowledge in the sense that it is justifiable, and, without justification for one's beliefs, knowledge seems to be illusory. Knowledge is standardly defined by epistemologists as justified true belief. One can happen to possess true beliefs; however, if one does not possess a proper justification for a specific belief, one's belief does not qualify as a knowledge claim (even if it happens to be true). If a person cannot freely infer the best explanation, then she has no justification that her belief really is the best explanation. Without justification, knowledge goes down the drain. All one is left with is question-begging assumptions, so rendering all one's thinking a series of logical fallacies.

If premise (3) of the Freethinking Argument is true, then such a dire conclusion becomes inarguable, because to argue against it, one must appeal to rationality and assume one possesses knowledge that the premise is 
faulty. Thus, objecting to this premise would actually affirm it-along with the very point made here.

Given the naturalist's view of scientific determinism, or the Calvinist's view of divine determinism, how could anyone ever freely choose to engage in the process of rationality? If everything is determined by naturalistic 'cause and effect'—or by God-then this would include all of our thoughts and beliefs. All supposed human choices become illusory if this is the case. This would include the choice to follow the laws of logic and to think rationally. The scientific determinist and the divine determinist (if correct) would not have come to their conclusions based on their intelligence or by choosing to examine the evidence to infer the best explanation. No, such conclusions would be simply determined by chemistry and physics, or by God, and would have nothing to do with knowledge, logic, or rationality. If exhaustive determinism is true, 'there is no free will involved either in assessing whether one thought is better than another' (Smith 2013). William Lane Craig makes this point clear:

There is a sort of dizzying, self-defeating character to determinism. For if one comes to believe that determinism is true, one has to believe that the reason he has come to believe it is simply that he was determined to do so. One has not in fact been able to weigh the arguments pro and con and freely make up one's mind on that basis. The difference between the person who weighs the arguments for determinism and rejects them and the person who weighs them and accepts them is wholly that one was determined by causal factors outside himself to believe and the other not to believe. When you come to realize that your decision to believe in determinism was itself determined and that even your present realization of that fact right now is likewise determined, a sort of vertigo sets in, for everything that you think, even this very thought itself, is outside your control. Determinism could be true; but it is very hard to see how it could ever be rationally affirmed, since its affirmation undermines the rationality of its affirmation (Craig 2012).

While it seems intuitively obvious that humans possess libertarian free will and make real choices (at least occasionally), to deny this is to reject rationality and the knowledge (justified, true belief) gained via the process of rational affirmation. Therefore, a determinist has no grounds to state that determinism is true. In fact, it is an utterly non-rational statement (regardless of whether or not determinism is true). If the determinist happens to be correct about determinism, it is impossible for libertarian free will to exist, and it seems to follow that the ability to rationally affirm one's beliefs is lost as well.

The authors are appealing to logical inference and the process of rationality to come to these conclusions. A supportive argument might be put this way: 
1. Rationality requires deliberation.

2. Deliberation requires libertarian free will.

3. Therefore, rationality requires libertarian free will.

This mini-argument hinges on the word 'deliberation', which might be defined this way: 'To weigh in the mind; to consider and examine the reasons for and against a measure to estimate the weight of force of arguments, or the probable consequences of a measure, in order to a choice or decision; to pause and consider' (Webster 1828).

Given this definition, is it possible to truly deliberate without libertarian free will? If the non-rational laws of nature and past events, or God, exhaustively determine a person's considerations, examinations, and estimations, then that person cannot rationally affirm, justify, or provide any warrant that her beliefs are true (including her belief that determinism is true). Libertarian free will is required to be able to evaluate one's thoughts/beliefs and to deliberate in the truest sense. If deliberation is impossible, then it seems, so is rationality.

If deliberation is the process of considering and evaluating various reasons for and against certain actions (physical and mental) and if this process implies libertarian free will, then that means a person is free to choose what he ultimately believes (at least occasionally). This is referred to as 'doxastic voluntarism' (Moreland and Craig 2003: 87).

There are two different views regarding doxastic voluntarism: direct and indirect. According to direct doxastic voluntarism, one has direct, immediate control over all one's beliefs. According to indirect doxastic voluntarism, one is free to do certain things to move oneself to a position to change one's beliefs. Now direct doxastic voluntarism seems utterly absurd, as no one can simply choose to believe any proposition (or not) at any given moment. For instance, even if we (the authors) were offered a billion dollars to really choose to believe at this very moment that there is no such thing as the reality of the past or that God does not exist, it would be impossible for us to really believe these propositions are true. However, if indirect doxastic voluntarism is true, a person is truly responsible for her beliefs in the sense that she can exercise freedom at various points in her life. For instance, she can choose what she will or will not consider, how she will view a particular subject, if she is open to a particular line of argumentation or not, and so forth. Moreland and Craig recognize this when they declare: 'Libertarians claim that we hold people responsible for what they believe (and the New Testament would seem to command people to believe certain things and hold them accountable for their choice to believe or not to believe), and this requires some form of doxastic voluntarism to be true' (Moreland and Craig 2003: 87). 
All who hold to exhaustive determinism (natural or divine) reject the idea of indirect doxastic voluntarism because it implies libertarian free will to indirectly choose what they will or will not believe. By denying indirect doxastic voluntarism, they are admitting that they are in effect doing so without good reason (or any reason at all). At the very least, determinists of any stripe must affirm that they have not freely chosen to believe indirect doxastic voluntarism is false!

If one possesses libertarian free will, then she can rationally examine a thought or evaluate a belief before choosing to affirm it. If one does not possess the ability to examine or evaluate her thoughts and beliefs, what basis would she have to think that her thoughts and beliefs are any good (or true)?

Furthermore, the Bible seems to take the way a person thinks and what she believes quite seriously. Consider, for example, the words of Paul: 'We destroy arguments and every lofty opinion raised against the knowledge of God, and take every thought captive to obey Christ' (2 Corinthians 10:5). Paul is claiming that we ought to take our thoughts captive to obey Christ. According to Paul's other writings, Jesus Christ is ultimate reality (Colossians 1:16). Thus, when we take our thoughts captive to obey Christ, we are thinking true thoughts. This is because truth corresponds to reality (at least if the correspondence theory of truth corresponds to reality). Does not Paul imply that persons are responsible free thinkers in the libertarian sense? In 2 Corinthians 10:5, then, Paul makes it clear that not all of a person's thoughts are causally determined and forced upon her from external sources. That is to say that individuals are ultimately responsible for their own thoughts (at least some of them).

Moreover, in Colossians 2:8, Paul states that people can be taken captive by incorrect thinking. Hence, Paul believes that humanity is engaged in a battle, a battle that is 'not against flesh and blood' (Ephesians 6:12). Whether a person realizes it or not, all are in a battle for the mind; one's thoughts must be taken captive before their thoughts take one captive. People are responsible for their thoughts and, thus, ought to be free thinkers.

Again, Jesus is clear that people can $\sin$ in their minds without even moving a finger. Consequently, Jesus teaches that the manner in which a person thinks is just as important as the way she moves her body. This is why if one hates another person in her heart, she is guilty of murder in the eyes of God (Matthew 5:21-26). It follows that one can be tempted to sin, and one can sin, in the mind alone.

This whole approach to thinking is harmonious with what Paul says in 1 Corinthians 10:13 regarding temptation to sin: 'No temptation has overtaken you that is not common to man. God is faithful, and he will not let you be tempted beyond your ability, but with the temptation he will also provide 
the way of escape, that you may be able to endure it.' In short, what this verse states is that every time a person (at least a Christian) has sinned, God has provided a way out so that the person need not sin. Hence when a person sins, the person was able not to $\sin$. Sin was a free choice. This is free will of the libertarian variety. Since a person is able not to sin, she is responsable for the sin. Thus, when one sins, one cannot claim 'The devil made me do it!' And certainly one cannot say, 'God made me do it!' One has the ability to refrain from sin, and one must take responsibility for one's thoughts (2 Corinthians 10:5; Colossians 2:8) and actions.

In summary, if determinism is true and one lacks free will, then one has not really 'made up one's own mind' about any belief, since all of one's beliefs are the result of factors outside of one's control (e.g., the laws of nature or God). If one's beliefs just so happen to correspond to reality, it seems as if one can never justify one's beliefs by rationally affirming them. Thus, unlike libertarianism, determinism seems to be self-refuting.

We have argued in favor of the first pillar of Molinism, namely, that humans have libertarian free will. Let us turn now to the second pillar, namely, that God has middle knowledge.

\section{Middle Knowledge}

The notion that God has middle knowledge is connected to the debate about the logical structure or order of God's knowledge. Both the divine determinist and the Molinist agree that God's knowledge has various levels or stages that are related by a logical order. It is important to note that a logical order is not necessarily a temporal order. For example, the words in a sentence are logically, but not temporally, prior to the meaning of the sentence; and the left-hand of an equation (e.g., ' $2+4$ ') is logically, but not temporally, prior to the answer or right-hand of the equation (e.g., ' 6 '). In a similar way, the stages of God's knowledge are logically, not temporally, prior or posterior to each other, since God experiences these stages eternally or timelessly.

The divine determinist and the Molinist also agree (1) that God's natural knowledge is logically prior (hereafter simply 'prior') to God's creative decree (i.e., God's decision to create the world); (2) that God's free knowledge is logically posterior (hereafter simply 'posterior') to God's creative decree; and (3) that God has knowledge of all true, contingent counterfactuals. Natural knowledge refers to knowledge of all necessary truths, such as $2+4=6$ or the set of possible worlds. This type of knowledge is independent of God's free will. Free knowledge refers to knowledge of all contingent truths about the actual world, including the past, present, and future. This type of knowledge depends on which world God freely decides to actualize. A counterfactual is a conditional statement of the form "If it were the case that $p$, 
then it would be the case that $q$, where $p$ and $q$ are propositions. An important type of counterfactual is a counterfactual of creaturely freedom (CCF), which has the form 'If $P$ were in $C$, then $P$ would freely perform $A$ ', where $P$ is some person, $C$ is some set of circumstances, and $A$ is some action. Now, although the divine determinist and the Molinist typically agree that God knows all counterfactuals (including all CCFs), they disagree about where in the logical sequence of stages this knowledge is situated. According to the divine determinist, God's counterfactual knowledge is part of his free knowledge, which is posterior to God's creative decree:

\author{
Stage 1: God's natural knowledge \\ Stage 2: God's creative decree \\ Stage 3: God's free knowledge (including knowledge of counterfactuals)
}

Consequently, God knows what every person would do in whatever set of circumstances in which they find themselves, and God knows this because he determines what every person will do in each set of circumstances.

According to the Molinist, however, God's knowledge of counterfactuals is situated between God's natural knowledge and free knowledge (hence the term 'middle knowledge'), and it is logically prior to God's creative decree:

$\begin{array}{ll}\text { Stage 1: } & \text { God's natural knowledge } \\ \text { Stage 2: } & \text { God's middle knowledge } \\ \text { Stage 3: } & \text { God's creative decree } \\ \text { Stage 4: } & \text { God's free knowledge }\end{array}$

Since middle knowledge is prior to the creative decree, it is independent of God's free will and, as a result, God does not determine the truth-value of CCFs. Middle knowledge thus allows creatures to possess free will.

Now, why think that God has middle knowledge? Molinists have put forward several arguments in favor of middle knowledge. In this article, however, we will defend just one argument for middle knowledge. We wish to show that a being that has middle knowledge is greater than a being that lacks middle knowledge. Our argument may be phrased as follows:

(A1) If God lacks middle knowledge, then God is not a maximally great being.

(A2) God is a maximally great being.

(A3) Therefore, God has middle knowledge.

The Molinist and the divine determinist both affirm (A2), rendering the crucial premise here (A1). But why think (A1) is true? It seems clear, at least to us, that a being whose knowledge of counterfactuals does not depend on the being's prior will, decisions, or actions is greater than a being whose 
knowledge of counterfactuals does depend on these. To illustrate this, consider the following thought experiment. Suppose that both Sally and Jones know that

(B) If Smith were to run for president, Smith would win and become president.

Suppose further that Smith will eventually run for president and win, such that (B) is true, and that Sally and Jones know (B) before Smith runs for president. Furthermore, suppose that Sally knows (B) only because she has rigged the election in such a way that Smith would win if he runs for president. In this case, Sally's knowledge of (B) is not extraordinary or remarkable. Why should we be impressed by the fact that Sally knows (B), since we know that she intentionally performed actions that would guarantee (B)? Sally's knowledge of (B) depends on her prior knowledge of the rigged election.

However, suppose that, unlike Sally, Jones has not rigged the election and he knows (B) simply by virtue of his nature. Hence, Jones's knowledge of (B) does not depend on his prior knowledge or actions. In this case, Jones's knowledge of (B) is truly remarkable. Indeed, we should be very impressed by the fact that Jones has the ability to know (B) without having to do anything. Thus, it seems clear that Jones's knowledge of (B) is greater than Sally's knowledge of (B) precisely because Jones's knowledge does not depend on his prior will, decisions, or actions, whereas Sally's knowledge does depend on her prior will, decisions, or actions.

The above thought experiment illustrates that a being whose knowledge of counterfactuals does not depend on the being's prior will, decisions, or actions is greater than a being whose knowledge of counterfactuals does depend on one or more of these. Now, since a maximally great being is omniscient, this being will know all counterfactuals either prior to its will (i.e., have middle knowledge) or posterior to its will (i.e., lack middle knowledge). However, as we have seen, it is greater to know all counterfactuals prior to one's will; therefore, a maximally great being must have middle knowledge. Since God is a maximally great being, it follows that God has middle knowledge.

In order to avoid this conclusion, one might press the so-called grounding objection, according to which middle knowledge is impossible because there is nothing that grounds CCFs. The alleged problem is that, if CCFs are independent of God's will, then nothing makes them true (or there is nothing in virtue of which they are true). Consequently, CCFs either lack truthvalues or they are all false. Either way, the grounding objection asserts that God cannot know such counterfactuals. Unfortunately, since the advocates of the grounding objection usually do not explain what they mean by 
'grounding', it is difficult to see what exactly the problem is. Perhaps the objector means that

(C1) A true contingent proposition is true in virtue of the existence of some concrete object(s).

Accordingly, for example, if the proposition 'Jones is eating eggs' is true, it is true in virtue of the existence of Jones and his action of eating eggs. However, (C1) implies that contingent propositions about objects that no longer exist are false. The proposition 'Dinosaurs no longer exist today', for example, is false because there exists no concrete object that renders the proposition true. The objector will have to adjust (C1) as follows:

(C2) A true contingent proposition is true in virtue of the existence or past existence of some concrete object(s).

But then what about future contingent propositions, such as the proposition 'It will rain in Spain in exactly ten years from today'? If I asserted this proposition ten years ago, and it does, in fact, rain in Spain today, then surely it is correct to say that I asserted a true proposition ten years ago. Thus, to account for future contingent propositions, the objector should adjust (C2) as follows:

(C3) A true contingent proposition is true in virtue of the existence, past existence, or future existence of some concrete object(s).

(C3), however, does not account for certain negative existential propositions, such as the proposition 'Unicorns have not, do not, and will not exist'. Such a proposition is surely true even though the past, present, or future existence of one or more concrete objects does not render it true. Hence, (C3) will have to be adjusted further as follows:

(C4) A true contingent proposition is true in virtue of the existence, past existence, future existence, or non-existence of some concrete object(s).

We can now see that it is really facts (or obtaining states of affairs), and not the existence of some concrete object(s), that ground true contingent propositions. Thus, 'Dinosaurs no longer exist today' is grounded by the fact that dinosaurs no longer exist today, 'it will rain in Spain ten years from today' is grounded by the fact that it will rain in Spain ten years from today, and 'unicorns do not exist' is grounded by the fact that unicorns do not exist. Consequently, if the objector insists that CCFs must be grounded or have truthmakers, then the Molinist may simply respond that CCFs are grounded by 
counterfactual facts. For example, the CCF 'If Jones grew up in Germany, then he would learn to speak French' is grounded by the fact that if Jones grew up in Germany, then he would learn to speak French. Thus, the Molinist may simply adjust (C4) as follows:

(C5) A true contingent proposition is true in virtue of the fact that some concrete object(s) exist, or did exist, or will exist, or don't exist, or would exist under specific conditions.

(C5) seems to be as reasonable as (C4) and, thus, if the grounding objection is to succeed, one must show why (C5) is implausible while (C4) is plausible. This challenge, to our knowledge, has not yet been met. Therefore, we believe that the grounding objection is unsuccessful and middle knowledge is possible. We thus have good reasons to believe that God, as a maximally great being, has middle knowledge.

\section{Conclusion}

We have argued that humans are free in the libertarian sense because, if determinism is true and one lacks free will, then one's beliefs cannot be rationally justified; however, many of our beliefs are rationally justified. We then argued that God has middle knowledge, since (i) God is a maximally great being and (ii) a being that has middle knowledge is greater than a being that lacks middle knowledge. Thus, we believe there are good reasons to affirm the two essential pillars of 'Mere Molinism'.

\section{Bibliography}

Calvin J (1845) Institutes of the Christian Religion. Beveridge H (trans). Edinburgh: Calvin Translation Society.

Craig WL (2012) Molinism vs. Calvinism: Troubled by Calvinists. Available at: http://www.reasonablefaith.org/molinism-vs-calvinism.

Harris S (2012) Free Will. New York, NY: Free Press.

Hawking S (2010) The Grand Design. New York, NY: Bantam.

Kane, R (2002) Aristotle. In Kane R (ed) The Oxford Handbook of Free Will. Oxford: Oxford University Press.

MacGregor KR (2015) Luis de Molina: the Life and Theology of the Founder of Middle Knowledge. Grand Rapids, MI: Zondervan.

Moreland JP and Craig WL (2003) Philosophical Foundations for a Christian Worldview. Downers Grove, IL: InterVarsity.

Smith S (2013) Personal communication.

Webster N (1828) American Dictionary of the English Language. Available at: http://webstersdictionary1828.com/ 